\title{
Intraventricular neuroepithelial tumors: surgical outcome, technical considerations and review of literature
}

\author{
A. Kaywan Aftahy ${ }^{1 *}$ (D) Melanie Barz ${ }^{1}$, Philipp Krauss ${ }^{1}$, Friederike Liesche ${ }^{2}$, Benedikt Wiestler ${ }^{3}$, \\ Stephanie E. Combs ${ }^{4,5,6}$, Christoph Straube ${ }^{4}$, Bernhard Meyer ${ }^{1}$ and Jens Gempt ${ }^{1}$
}

\begin{abstract}
Background: Intraventricular neuroepithelial tumors (IVT) are rare lesions and comprise different pathological entities such as ependymomas, subependymomas and central neurocytomas. The treatment of choice is neurosurgical resection, which can be challenging due to their intraventricular location. Different surgical approaches to the ventricles are described. Here we report a large series of IVTs, its postoperative outcome at a single tertiary center and discuss suitable surgical approaches.
\end{abstract}

Methods: We performed a retrospective chart review at a single tertiary neurosurgical center between 03/2009-05/ 2019. We included patients that underwent resection of an IVT emphasizing on surgical approach, extent of resection, clinical outcome and postoperative complications.

Results: Forty five IVTs were resected from 03/2009 to 05/2019, 13 ependymomas, 21 subependymomas, 10 central neurocytomas and one glioependymal cyst. Median age was 52,5 years with $55.6 \%$ (25) male and $44.4 \%$ (20) female patients. Gross total resection was achieved in 93.3\% (42/45). 84.6\% (11/13) of ependymomas, 100\% (12/21) of subependymomas, $90 \%(9 / 10)$ of central neurocytomas and one glioependymal cyst were completely removed. Postoperative rate of new neurological deficits was 26.6\% (12/45). Postoperative new permanent cranial nerve deficits occurred in one case with 4th ventricle subependymoma and one in 4th ventricle ependymoma. Postoperative KPSS was 90\% (IR 80-100). 31.1\% of the patients improved in KPSS, 48.9\% remained unchanged and 20\% declined. Postoperative adverse events rate was 20.0\%. Surgery-related mortality was $2.2 \%$. The rate of shunt/cisternostomy-dependent hydrocephalus was $13.3 \%$ (6/45). 15.4\% of resected ependymomas underwent adjuvant radiotherapy. Mean follow-up was 26,9 $( \pm 30.1)$ months.

Conclusion: Our surgical findings emphasize satisfactory complete resection throughout all entities. Surgical treatment can remain feasible, if institutional experience is given. Satisfying long-term survival and cure is possible by complete removal. Gross total resection should always be performed under function-remaining aspects due to mostly benign or slow growing nature of IVTs. Further data is needed to evaluate standard of care and alternative therapy options in rare cases of tumor recurrence or in case of patient collective not suitable for operative resection.

Keywords: Intraventricular tumor, Neuroepithelial, Ependymoma, Subependymoma, Central neurocytoma, Surgical technique, Extent of resection, Neurosurgery

\footnotetext{
* Correspondence: kaywan.aftahy@tum.de

'Department of Neurosurgery, Technical University Munich, Medical Faculty,

School of Medicine, Klinikum rechts der Isar, Ismaninger Str. 22, 81675

Munich, Germany

Full list of author information is available at the end of the article
}

C C The Author(s). 2020 Open Access This article is licensed under a Creative Commons Attribution 4.0 International License, which permits use, sharing, adaptation, distribution and reproduction in any medium or format, as long as you give appropriate credit to the original author(s) and the source, provide a link to the Creative Commons licence, and indicate if changes were made. The images or other third party material in this article are included in the article's Creative Commons licence, unless indicated otherwise in a credit line to the material. If material is not included in the article's Creative Commons licence and your intended use is not permitted by statutory regulation or exceeds the permitted use, you will need to obtain permission directly from the copyright holder. To view a copy of this licence, visit http://creativecommons.org/licenses/by/4.0/. The Creative Commons Public Domain Dedication waiver (http://creativecommons.org/publicdomain/zero/1.0/) applies to the data made available in this article, unless otherwise stated in a credit line to the data. 


\section{Background}

Intraventricular neuroepithelial tumors (IVT) are rare lesions and account for $2-7 \%$ of intracranial tumors [1]. IVTs summarize a group of different pathological entities, namely ependymoma, subependymoma, central neurocytoma and glioependymal cysts. These lesions are mainly benign and arise from the ventricular wall or the choroid plexus [2-4]. Due to their benign character and ventricular location, they first become apparent by signs of hydrocephalus or are incidental findings. As IVTs are regularly not targetable by radiation or systemic therapy, until now, surgical resection presents the treatment of choice.

One of the first successful intraventricular resections were performed by Krause in 1913 by an infratentorial supracerebellar approach [5]. Jamieson's [6] and Poppen's [7] occipital trans-tentorial, and Dandy's posterior transcallosal approach [8] were further landmark techniques for entering the ventricular system.

Over the last decades, further authors have proposed technically advantaged approaches to the ventricular system. Regarding the fourth ventricle, approaches as the transvermian [9], a subtonsillar-transcerebellomedullary [10], a superior transvelar approach [11] or also endoscopic approaches $[12,13]$ were described with claiming to be the superior one. The transvermian approach has been performed frequently in history, but data showed high rates of cerebellar mutism and disequilibrium [14, 15]. To enter the lateral and/or third ventricle a variety of approaches including the frontal-transcortical, the anterior/posterior interhemispheric-transcallosal and the contralateral interhemispheric-transfalcinetransprecuneal approach have been described [16-21].

Due to the above-mentioned diversity, aim of this manuscript is to share our experience with a large series of IVTs at a single tertiary neurosurgical center by using technical acceptable and standardized approaches to the ventricle system. With focus on few, but wellexperienced approaches this study also want to show their sufficiency and reduction of perioperative morbidity. Furthermore, due to the rare natural history of IVTs, the heterogeneity was chosen to discuss this study from a surgical and technical point of view.

\section{Methods}

\section{Study design and outcome parameters}

We performed an observational retrospective singlecenter study. Adult patients who underwent surgery for IVT between March 2009 and May 2019 were included. The clinical records of patients were analyzed according to surgical approach, pre- and postoperative neurological/ophthalmological status, Karnofsky Performance Status Scale (KPSS) and adverse events according to the Clavien Dindo scale (CDG) during follow up visits.
Extent of resection was determined by pre- and postoperative $\mathrm{T} 1 \pm$ contrast agent $3.0 \mathrm{~T}$ MRI images. Infant patients and patients not undergoing surgery were excluded. All surgeries were performed under general anesthesia by experienced neurooncological surgeons in our neurosurgical institute. For details on the surgical approach see discussion/surgical approach.

\section{Statistical analysis}

Statistical analysis, including descriptive data analysis, was performed using IBM SPSS Statistics Version 26.0 (SPSS Inc., IBM Corp., Armonk, NY, USA). Normal distribution was assumed according to the central limit theorem. Data in text and graphs are shown as median with interquartile range (IQR) or mean \pm standard deviation (SD). Survival analyses were performed using KaplanMeier estimates for univariate analysis and Cox regression proportional hazards model for multivariate analysis. A $p$ value $\leq .05$ was considered significant and indicated by “*”, $p$ values $\leq .01$ were indicated by “**”, and values $\leq .001$ by “***”.

\section{Ethics approval and consent to participate}

Our study was approved by the local ethics committee, Technical University Munich, School of Medicine, ( $\left.{ }^{\circ} 5625-12\right)$. It is conducted in accordance with the ethical standards of the 1964 Declaration of Helsinki and its later amendments [22]. The requirement for written informed consent was waived by the ethics committee.

\section{Results}

\section{Patient population}

Forty-five patients with IVT underwent surgical resection between March 2009 and May 2019. Median age was 52,5 years with $55.6 \%$ (25) male and $44.4 \%$ (20) female patients. $15.6 \%(7 / 45)$ of the patients were asymptomatic, tumors were discovered incidentally. 84.4\% 38/ 45) were symptomatic-including cephalgia, nausea, diplopia, cranial nerve deficits, ataxia/imbalance and further symptoms. The median preoperative KPSS was 90\% (IR 90-90) and the median postoperative KPSS was 90\% (IR 80-100). No evidence of spinal drop metastasis was present on preoperative (holo-spinal) MR imaging (Table 1).

\section{Tumor related findings and location}

Histopathological analysis revealed ependymoma in 13 cases, subependymoma in 21 cases, neurocytomas in 10 cases and glioependymal cyst (GEC) in one case, confirmed by histopathological examination as well. 44.4\% (20/45) underwent a frontal-transcortical-keyhole, 48.9\% (22/45) a median suboccipital telovelar, 2.2\% (1/45) a frontotemporal, further $2.2 \%(1 / 45)$ a supracerebellar-infratentorial and another $2.2 \%(1 / 45)$ a parietal transcortical approach. In three 
Table 1 Demographics and preoperative characteristics

\begin{tabular}{|c|c|c|c|c|c|}
\hline Demographics \% (N) or mean/median (SD/IR) & Ependymoma (13) & Subependymoma (21) & Central Neurocytoma (10) & GEC (1) & Total (45) \\
\hline Age & $54.7( \pm 20.2)$ & $58( \pm 12)$ & $41.7( \pm 15.2)$ & 18 & $52.5( \pm 17.1)$ \\
\hline \multirow[t]{2}{*}{ Sex } & M 46.2\% (6) & M 61.9\% (13) & M 60.0\% (6) & M 0 & M 25 (55.6\%) \\
\hline & F $53.8 \%(7)$ & F $38.1 \%(8)$ & F $40.0 \%(4)$ & F 1 & F 20 (44.4\%) \\
\hline \multicolumn{6}{|l|}{ Clinical presentation } \\
\hline Pre-operative KPSS & $90 \%(\operatorname{IR~80-90)}$ & $90 \%(I R$ 90-90) & 90 (IR 90-90) & 90 & 90 (IR90-90) \\
\hline Asymptomatic & $30.8 \%(4)$ & $9.6 \%(2)$ & $10.0 \%(1)$ & 0 & $15.6 \%(7)$ \\
\hline Recurrence & $15.4 \%(2)$ & 0 & $10.0 \%(1)$ & & $6.6 \%(3)$ \\
\hline Cranial nerve deficits & $\begin{array}{l}\text { III } 7.7 \%(1) \\
\text { V } 7.7 \%(1) \\
\text { IX } 15.4 \%(2) \\
\text { XII } 7.7 \%(1)\end{array}$ & 0 & 0 & 0 & $11.1 \%(5)$ \\
\hline Diplopia & $7.7 \%(1)$ & $4.8 \%(1)$ & $10.0 \%(1)$ & 0 & $6.7 \%(3)$ \\
\hline Cephalgia & $38.5 \%(5)$ & $42.9 \%(9)$ & $80.0 \%(8)$ & 0 & $48.9 \%(22)$ \\
\hline Vertigo/Nausea & 0 & $47.6 \%(10)$ & $50.0 \%(5)$ & 0 & $33.3 \%(15)$ \\
\hline Hydrocephalus / Concentration disorder & $23.1 \%(3)$ & $23.8 \%(5)$ & $20.0 \%(2)$ & $100 \%(1)$ & $24.4 \%(11)$ \\
\hline Disequilibrium / Ataxia / Cerebellar symptoms & $30.8 \%(4)$ & $9.5 \%(2)$ & 0 & 0 & $13.3 \%(6)$ \\
\hline Dysphagia / Dysarthria & $7.7 \%(1)$ & 0 & 0 & 0 & $2.2 \%(1)$ \\
\hline Hemihypesthesia & $7.7 \%(1)$ & 0 & 0 & 0 & $2.2 \%(1)$ \\
\hline
\end{tabular}

patients with 4th ventricle tumors, which extended more caudally, a $\mathrm{C} 1$ arch resection was performed additionally.

$92.3 \%(12 / 13)$ of the ependymomas were located in the 4 th ventricle, one ependymoma was located in the left temporal horn. $52.4 \%(11 / 21)$ of the subependymomas were located in the lateral ventricles, $47.6 \%(10 / 21)$ in the fourth ventricle. $90.0 \%(9 / 10)$ of the central neurocytomas were found in lateral ventricles (three right, five left), one was located at the floor of the 3rd ventricle. The only GEC, which caused an occlusive hydrocephalus, was located at the roof of the 3rd ventricle (Table 2).

In total, $92.3 \%(12 / 13)$ of the ependymomas and $47.6 \%$ $(10 / 21)$ of the subependymomas were located infratentorial (4th ventricle) but none of the central neurocytomas or the GEC. In sum, $48.9 \%(22 / 45)$ of all analyzes tumors were located in the 4 th ventricle. $4.4 \%(2 / 45)$ of the tumors were located in the 3 rd ventricle, one central neurocytoma and the GEC. 46.7\% (21/45) of the tumors were found in the lateral ventricles (1/13 ependymomas, 11/21 subependymomas, 9/10 central neurocytomas).

\section{Functional outcome and surgical complications}

Complete removal could be achieved in 93.3\% (42/45) (Table 3). No statistically significant predictive factors regarding overall survival could be analyzed in a univariate analysis. $2.6 \%(12 / 45)$ developed new postoperative neurological deficits, $58.3 \%$ were permanent during follow-up. $20.0 \%$ (2/10) of patients with central neurocytoma presented with a latent hemiparesis and 20.0\% (2/ 10) with transient dysarthria. One patient with a 4th ventricle ependymoma developed postoperative hemorrhagic infarction with KPSS decline from 80.0 to $40.0 \%$. This patient also developed a shunt-dependent hydrocephalus. One patient with 4th ventricle subependymoma died due to central lung artery embolism postoperatively. $13.3 \%(6 / 45)$ of the patients had postoperative ventriculitis/meningitis (2/21 subependymomas and 4/10 central neurocytomas), four were aseptic and two (both central neurocytomas) had positive proof of germs. Another patient with a central neurocytoma developed a postoperative ventricle entrapment and underwent cisternostomy. Adverse event rate was $20.0 \%$ (9/45). Postoperative KPSS was 90.0\% (IR 80100), 31,1\% (14/45) showed an improvement of KPSS (two ependymomas, nine subependymomas, two central neurocytoma and one GEC), but also 20.0\% (9/45) declined. The Clavien Dindo Scale (CDG) for postoperative adverse events showed satisfying postoperative outcomes through all entities (1, IR 1-2). Two resected WHO grade II ependymomas underwent adjuvant radiotherapy $(15,4 \%)$. Mean follow-up was 26.9 months (0-120 months).

\section{Discussion}

In our study we report a large single institution series of patients undergoing microsurgical resection of IVT. In a majority of cases, complete resection without neurological deficit could be achieved. A meticulous surgical planning and detailed anatomic knowledge is crucial for successful treatment. One has to separate approaches to 
Table 2 Tumor entity, WHO grade and intraventricular location

\begin{tabular}{|c|c|c|c|c|c|c|c|}
\hline \multirow{2}{*}{$\begin{array}{l}\text { Tumor \% }(\mathrm{N}) \text { or } \\
\text { mean/median } \\
\text { (SD/IR) }\end{array}$} & \multirow[t]{2}{*}{$\mathbf{N}$} & \multirow[t]{2}{*}{ WHO } & \multirow[t]{2}{*}{ Ventricle location } & \multicolumn{3}{|l|}{ Location within } & \multirow{2}{*}{$\begin{array}{l}\text { Approach according to } \\
\text { location }\end{array}$} \\
\hline & & & & Lateral ventricles & 3 rd & 4th & \\
\hline \multirow[t]{2}{*}{ Ependymoma } & 13 & $\begin{array}{l}\|(12) \\
\text { III (1) }\end{array}$ & $\begin{array}{l}\text { Lateral ventricle } 7.7 \% \\
\text { (1) }\end{array}$ & Left temporal horn (1) & & & Frontotemporal (1) \\
\hline & & & 4th ventricle $92.3 \%$ (12) & & & $\begin{array}{l}\text { Below str. Med 100\% } \\
\text { (12) }\end{array}$ & TeloVelar (12) \\
\hline \multirow[t]{2}{*}{ Subependymoma } & 21 & II (1) & $\begin{array}{l}\text { Lateral ventricle } 52.4 \% \\
\text { (11) }\end{array}$ & $\begin{array}{l}\text { Left frontal horn } 36.4 \% \\
\text { (4) } \\
\text { Right frontal horn } 63.6 \% \\
\text { (7) }\end{array}$ & & & $\begin{array}{l}\text { Frontal-Keyhole (10) } \\
\text { Parietal craniotomy (1) }\end{array}$ \\
\hline & & & 4th ventricle $47.6 \%$ (10) & & & $\begin{array}{l}\text { Below str. Med. } 90.0 \% \\
\text { (9) } \\
\text { Above str. Med. } 10.0 \% \\
\text { (1) }\end{array}$ & TeloVelar (10) \\
\hline \multirow[t]{2}{*}{$\begin{array}{l}\text { Central } \\
\text { Neurocytoma }\end{array}$} & 10 & $\|$ & $\begin{array}{l}\text { Lateral ventricle } 90.0 \% \\
\text { (9) }\end{array}$ & $\begin{array}{l}\text { Left frontal horn } 55.6 \% \\
\text { (5) } \\
\text { Right frontal horn } 44.4 \% \\
\text { (4) }\end{array}$ & & & Frontal-Keyhole (9) \\
\hline & & & 3rd ventricle $10.0 \%$ (1) & & $\begin{array}{l}\text { Floor } \\
(1)\end{array}$ & & $\begin{array}{l}\text { Infratententorial- } \\
\text { supracerebellar (1) }\end{array}$ \\
\hline GEC & 1 & - & 3rd ventricle 100\% (1) & & $\begin{array}{l}\text { Roof } \\
(1)\end{array}$ & & Frontal-Keyhole (1) \\
\hline Total & 45 & & $\begin{array}{l}\text { Lateral ventricle } 46.7 \% \\
(21) \\
3 \text { rd ventricle } 4.4 \%(2) \\
4 \text { th ventricle } 48.9 \%(22)\end{array}$ & & & & $\begin{array}{l}\text { Frontal-Keyhole } 44.4 \% \text { (20) } \\
\text { Others 6.7\% (3) } \\
\text { TeloVelar 48.9\% (22) }\end{array}$ \\
\hline
\end{tabular}

Table 3 Postoperative clinical characteristics, complications and outcome

\begin{tabular}{|c|c|c|c|c|c|}
\hline $\begin{array}{l}\text { Postoperative presentation \% }(\mathrm{N}) \text { or mean/ } \\
\text { median (SD/IR) }\end{array}$ & $\begin{array}{l}\text { Ependymoma } \\
\text { (13) }\end{array}$ & Subependymoma (21) & $\begin{array}{l}\text { Central Neurocytoma } \\
\text { (10) }\end{array}$ & GEC (1) & Total (45) \\
\hline Gross total resection & $84.6 \%(11)$ & $100 \%(21)$ & $90.0 \%(9)$ & $\begin{array}{l}100 \% \\
(1 / 1)\end{array}$ & $93.3 \%(29)$ \\
\hline New neurological deficits & $\begin{array}{l}\text { Vigilance } 7, \%(1) \\
\text { Ataxia } 15.4 \%(2)\end{array}$ & Ataxia 14.3\% (3) & $\begin{array}{l}\text { Hemiparesis 20.0\% (2) } \\
\text { Dysarthria 20.0\% (2) } \\
\text { Tinnitus } 10.0 \%(1) \\
\text { Vigilance } 10.0 \%(1)\end{array}$ & 0 & $26.6 \%(12)$ \\
\hline New cranial nerve deficits & $\begin{array}{l}\text { IX } 7.7 \%(1) \\
\text { XII } 7.7 \%(1)\end{array}$ & $\begin{array}{l}\text { VII } 4.8 \%(1) \\
\text { IX 4.8\% (1) } \\
\text { XII 4.8\% (1) }\end{array}$ & 0 & 0 & $11.1 \%(5)$ \\
\hline Post-operative KPSS & $90 \%(I R 70-100)$ & 100\% (IR 85-100) & $90 \%(\operatorname{IR~87,5-100)}$ & $100 \%$ & $\begin{array}{l}90 \%(\operatorname{lR} 80- \\
100)\end{array}$ \\
\hline KPSS unchanged & $61.5 \%(8)$ & $38.1 \%(8)$ & $60.0 \%(6)$ & 0 & $48.9 \%(22)$ \\
\hline KPSS declined & $23.1 \%(3)$ & $19.0 \%(4)$ & $20.0 \%(2)$ & 0 & $20.0 \%(9)$ \\
\hline KPSS improved & $15.4 \%(2)$ & $42.9 \%(9)$ & $20.0 \%(2)$ & $\begin{array}{l}100 \% \\
(1)\end{array}$ & $31.1 \%(14)$ \\
\hline Clavien Dindo Scale (CDG) & $1(\mathrm{IR} 1-1,25)$ & $1( \pm \mid R$ 1-2) & $2(\operatorname{IR~1-3)}$ & 1 & 1 (IR 1-2) \\
\hline Complications & $\begin{array}{l}\text { CSF leakage } \\
7.7 \%(1)\end{array}$ & $\begin{array}{l}\text { Ventriculitis/Meningitis } \\
9.5 \%(2) \\
\text { Death } 4.8 \% \text { (1) }\end{array}$ & $\begin{array}{l}\text { Ventriculitis/ Meningitis } \\
40.0 \% \text { (4) } \\
\text { Ventr. entrapment } 10.0 \% \\
\text { (1) }\end{array}$ & 0 & $20.0 \%(9)$ \\
\hline Shunt/cisternostomy dependency & $15.4 \%(2)$ & $4.8 \%(1)$ & $30.0 \%(3)$ & 0 & $13.3 \%(6)$ \\
\hline Follow-up time in months & $16.4( \pm 14,1)$ & $316( \pm 33)$ & $26,4( \pm 36,9)$ & 72 & $26,9( \pm 30.1)$ \\
\hline
\end{tabular}


the lateral and third ventricle from approaches to infratentorial lesions and the fourth ventricle.

\section{Surgical approach \\ Approaches to the lateral and third ventricle}

To enter the lateral and third ventricle a variety of approaches have been described including the frontaltranscortical, the anterior/posterior interhemispherictranscallosal and the contralateral interhemispherictransfalcine-transprecuneal approach [16-21]. They allow excellent visualization of important anatomical structures like the thalamostriatal, anterior-septal and caudate veins, foramen of Monro and choroid plexus [23]. The transcortical approach is supposed to be associated with higher incidence of postoperative seizures and possible neurological deficits due to frontal lobe corticotomy and retraction of the supplemental motor or premotor area, but offers greater access and overview, especially in larger intraventricular lesions. The transcallosal approach is technically more demanding for proper dissection but is supposed to leave more cortical structures intact. However, transcallosal approach is also associated with higher morbidity and, in case of e.g. permanent damage of corpus callosum, with postoperative severe neurological deficits like the well-known "disconnection syndrome" [21, 23]. Taking these circumstances into consideration, the transcortical approach is preferred as a workhorse approach in our institute. Historically, high morbidity ratio in the literature initially led to disqualify the transcortical approach to the lateral and third ventricle at the beginning, but closer review of above-mentioned studies display that extended craniotomies and cortical exposure with rough retraction were transacted. Keyhole exposures are pushing minimal invasive philosophy of modern neurosurgery forward and are associated with less brain damage, comparable to injury caused by ventricle puncture, and offers a much more comfortable approach to the ventricle system [24].

Special attention has to be given to the head positioning to ensure optimal conditions. We perform surgery in supine position with $\sim 30^{\circ}$ anteroflection to elevate the preconorary part of the frontal lobe to the highest point and therefore minimize outflow of cerebrospinal fluid. This avoids collapsing ventricles and tearing of bridging veins. The craniotomy is usually centered on the coronary suture, a diameter of $\sim 3 \mathrm{~cm}$ is regularly sufficient to guarantee an adequate working canal. Figure 1 summarizes and reflects most prominent approaches.

\section{Approaches to the fourth ventricle}

To access the fourth ventricle, historically the transvermian approach was very popular. Still, this approach harbors the risk of cerebellar mutism and disequilibrium
$[14,15]$ leading to the development of the less invasive median suboccipital telovelar approach [25, 26].

Nevertheless, surgical morbidity of tumors of the fourth ventricle, mostly ependymomas, remains high with up to $30 \%$ adverse events. This is probably due to adhesive nature of the lesion and proximity of cranial nerves and their nuclei $[14,27,28]$. To reduce the risk for cranial nerve lesions, monitoring of cranial nerves and electrical intraoperative mapping of the floor of the fourth ventricle should be performed [29].

\section{Surgical outcome}

In the present series $44.4 \%(20 / 45)$ received resection via the microscopic frontal-keyhole approach and $48.9 \%$ $(22 / 45)$ a median suboccipital telovelar approach. Both approaches offer satisfying anatomical overview and thus facilitate possibility for safe complete tumor removal. Our postoperative complication rate of $20.0 \%$ with a shunt-dependency rate of $13.3 \%$ highlights the advantages of the keyhole as well as the median suboccipital telovelar approach. $10.0 \%(2 / 22)$ of median suboccipital telovelar approaches and three frontal approaches led to secondary shunt-implantation. 10.0\% (1/10) of resected central neurocytoma by a frontal approach led to postoperative ventricle entrapment with secondary cisternostomy. During resection of 4th ventricle lesions intraoperative neuromonitoring was performed to ensure safe functional resection and to reduce cranial nerve lesions. No postoperative wound healing disorders requiring surgical intervention were observed at all.

\section{Histopathological considerations}

IVTs share their predominantly intraventricular location as a result from specific peri- and intraventricular structures from which they arise. The ventricle system raises from telencephalic vesicles from the cranial end of the neural tube as ependymal-lined outpouchings. Into these vesicles the choroid plexus develops from an invagination of primitive pia, creating the choroidal fissure. The epithelium is composed of ependymal cells, origin of ependymomas. Subjacent to the ependymal lining is a subependymal plate of glial cells, from which subependymomas upraise. Residual neuronal precursor cells are found, inter alia, at the septum pellucidum, from which the central neurocytoma may arise [30].

\section{Ependymoma}

Ependymomas account for 1-5\% of intracranial central nervous neoplasms [31]. Arising from the ependymal cells of the ventricular wall, they can be found anywhere along the ventricular system and/or the spinal cord. Intracranially they show predominant occurrence in the posterior fossa e.g. the fourth ventricle (60\%) compared to supratentorial location $(40 \%)[1,14,32,33]$. Only few 


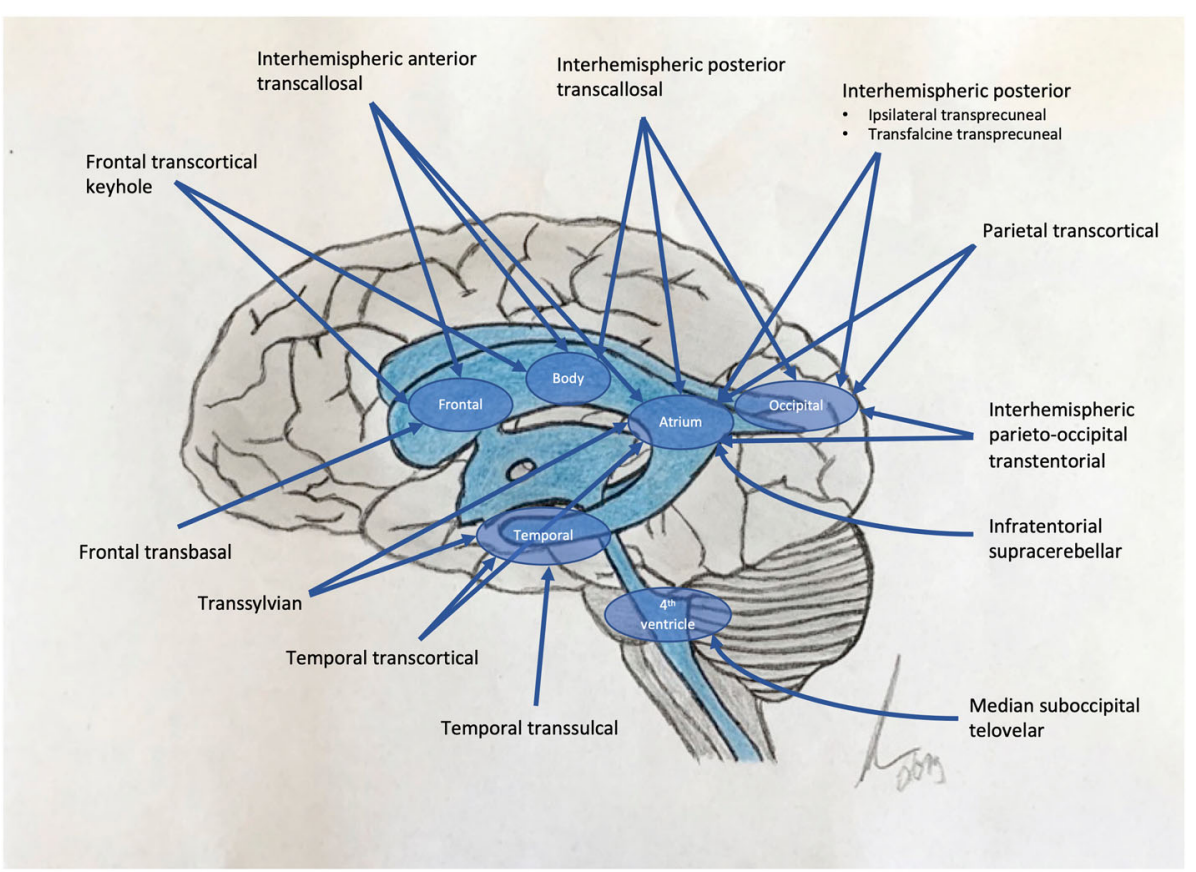

Fig. 1 Trajectories and approaches to the lateral and third ventricle. Lateral and third ventricle are shown in blue. Red arrows display the trajectory of the approaches and the parts of the ventricular system reached by that individual approach

case reports on extra-axial ependymomas exist (IEAE). Due to the rare entity of IEAE, no precise relation to intra-axial ependymomas can be made, but the vast majority are intra-axial lesions [34-36].

Ependymomas can be found at any age (Fig. 2), with a higher proportion of infratentorial lesions in pediatric patients (mean age 6y), compared to supratentorial tumor location (mean age 18-24y) [30, 31].

The treatment of choice is surgical removal of the tumor, gross total resection shows a prognostic role in recurrence-free and overall outcome. Nevertheless, regarding the mostly benign character of the lesion, avoidance of neurological deficits is of utmost importance and special attention has to be paid to the floor of the fourth ventricle - origin of multiple cranial nerve nuclei and/or ascending/descending tracts [14, 37-39].

In the present series, we achieved complete resection in $84,6 \%(11 / 13)$ and $83,3 \%(10 / 12)$ regarding 4 th ventricle ependymomas (Fig. 2), which coincides with the results of previous case series [14, 27, 28, 40-44] (Table 4). Rates of gross total resection $(82-91 \%$ of patients), cranial nerve deficits or shunt dependency differ among the reports of fourth ventricle ependymomas highlighting the complex anatomy of the fourth ventricle and its floor [42] [14]. In our series, 15.4\% (2/13) developed a postoperative shunt-dependent hydrocephalus and $7.7 \%(1 / 13)$ a deterioration of functional outcome (KPSS from 90 to 40\%) due to hemorrhagic infarction. One patient developed postoperative new cranial nerve deficits $(8.3 \%)$, representing a satisfying rate compared to previous reports $[14,27,28,40-44]$. Our findings coincide with prior studies highlighting good response to operative treatment of ependymomas, also in the fourth ventricle [14, 44]. Our higher rate of complete surgical removal was not associated to higher neurological morbidity or mortality [14, 27, 28, 40-44].

According to the recent 2018 EANO guidelines for diagnosis and treatment of ependymal tumors [45], the role of postoperative radiotherapy in patients with WHO grade II ependymoma undergoing complete removal is still controversial [46, 47]. Two larger retrospective analyses could not find any significant association between radiotherapy and survival outcome [45, 48, 49].

Regarding patients with anaplastic $\mathrm{WHO}^{\circ}$ III ependymoma or incomplete resection of $\mathrm{WHO}^{\circ} \mathrm{II}$ ependymomas, adjuvant radiotherapy is recommended [50]. In 2006, Combs et al. described non-inferiority regarding recurrence free survival of fractionated stereotactic radiotherapy (FSRT) compared to conventional radiotherapy, especially at the field borders [51], opposing earlier paradigms in radiotherapy [52].

In our series, two patients underwent postoperative radiotherapy after complete removal. One of them was an anaplastic $\mathrm{WHO}^{\circ}$ III ependymoma, following the actual guidelines of adjuvant therapy. The second case, in 2011, was a tanycytic ependymoma WHO ${ }^{\circ} \mathrm{II}$, in which the decision for adjuvant radiotherapy was based on ambiguous histopathological findings. 


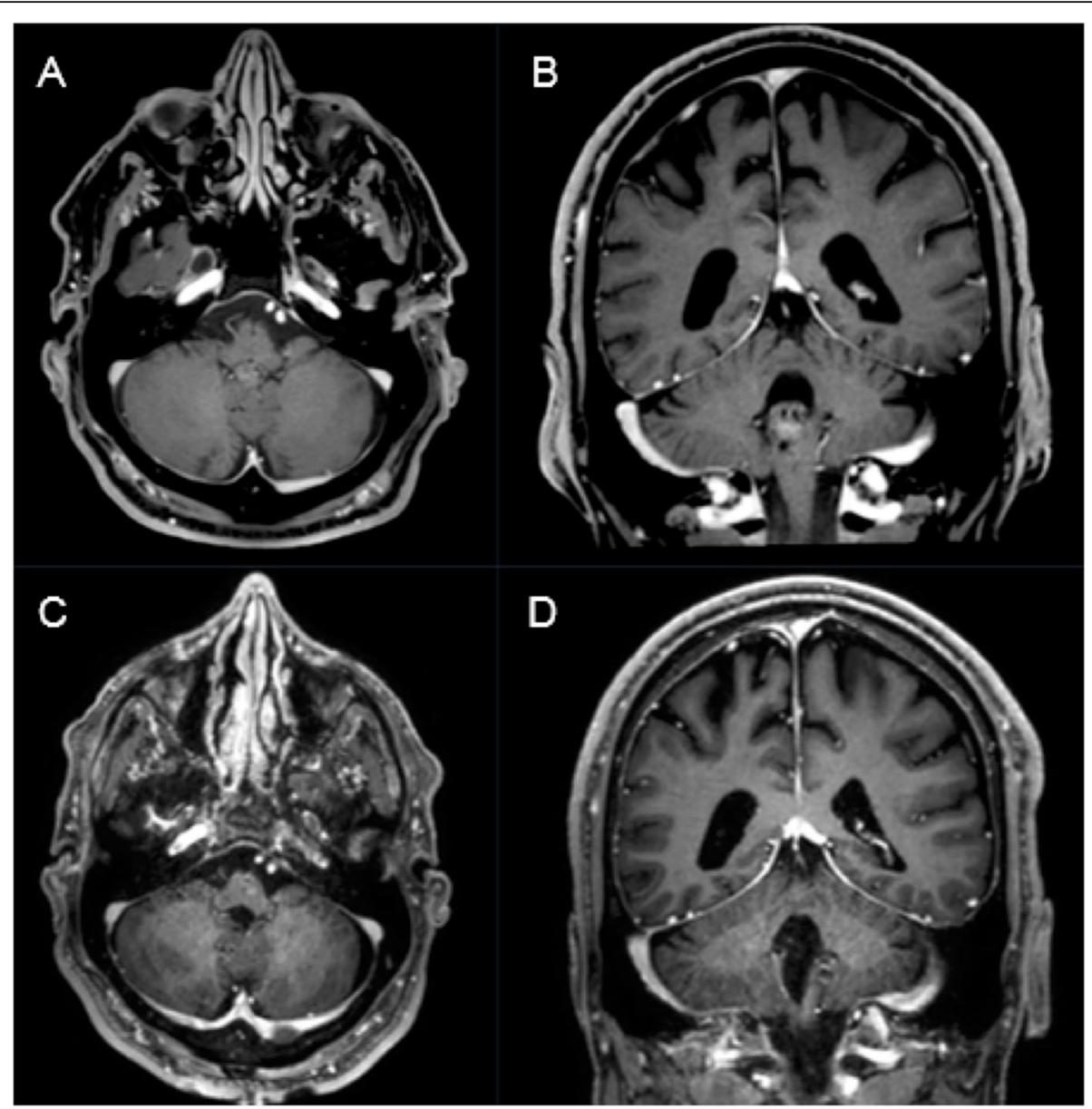

Fig. 2 A 27-year-old female patient presented with slight headache and intermitting vertigo. Preoperative T1-weighted gadolinium enhanced MRI showing a heterogeneously enhancing intraventricular mass on the ground of the fourth ventricle consistent with an ependymoma (a,b). Postoperative T1-weighted gadolinium enhanced MRI showing complete removal of the tumor through a median suboccipital telovelar approach (c,d). Pathological findings confirmed WHO grade II ependymoma

Table 4 Case series since 2000 of resected fourth ventricle ependymomas (values displayed are restricted to fourth ventricle ependymomas)

\begin{tabular}{|c|c|c|c|c|c|}
\hline Study & $\begin{array}{l}\text { Total patients } \\
\text { (adults) }\end{array}$ & $\begin{array}{l}\text { Ependymomas (4th } \\
\text { ventr.) }\end{array}$ & $\begin{array}{l}\text { Complete removal (GTR/ } \\
\text { ependymoma) }\end{array}$ & $\begin{array}{l}\text { Cranial nerve } \\
\text { deficits }\end{array}$ & Mortality \\
\hline Chai et al. [40] & 27 & 13 & $46.2 \%(6 / 13)$ & - & $0 / 27$ \\
\hline Rajesh et al. [41] & 15 & 1 & $0 \%(0 / 1)$ & - & $0 / 1$ \\
\hline Zaheer et al. [28] & 20 & 2 & $50.0 \%(1 / 2)$ & $0 \%$ & $0 / 2$ \\
\hline El-Bahy et al. [27] & 16 & 4 & $25.0 \%(1 / 4)$ & $50.0 \%$ & $0 / 4$ \\
\hline Tomasello et al. [42] & 45 & 11 & $91.0 \%(10 / 11)$ & $6.7 \%$ & - \\
\hline Winkler et al. [14] & 22 & 22 & $82.0 \%(18 / 22)$ & $26.0 \%$ & $0 / 22$ \\
\hline Gök et al. [43] & 21 & 5 & $80.0 \%(4 / 5)$ & $20.0 \%$ & $0 / 5$ \\
\hline Spagnoli et al. [44] & 26 & 26 & $69.0 \%(18 / 26)$ & - & $1 / 26$ \\
\hline $\begin{array}{l}\text { Aftahy et al. (present } \\
\text { series) }\end{array}$ & 45 & 12 & $83.3 \%(10 / 12)$ & $8.3 \%$ & $0 / 7$ \\
\hline
\end{tabular}




\section{Subependymoma}

Subependymomas account for $0.2-0.7 \%$ of intracranial neoplasms [1]. About $82 \%$ of subependymomas occur in patients older than 15 years and they show a male predominance (Fig. 3). Subependymomas are generally incidental findings, located in the walls of the fourth (66-70\%) and lateral ventricles (30-40\%) [53-55]. The foramen of Monro and spinal cord may also be affected [56].

Tumor location and extend of resection are the most important prognostic factors as recurrence has only been reported in case of subtotal resection [53, 57]. Their growth rate tends to be slow $[30,53]$. Rarely, aggressive tumors invading brain parenchyma or showing CSF dissemination are described as well [58]. As MR findings of subependymomas are very heterogenous histological confirmation of the diagnosis is mandatory due to several differential diagnosis including ependymomas and central neurocytomas. Thus, a "watch and wait" strategy with regular MRI follow-ups can lead to undertreatment in case of more aggressive entities mistaken for a subependymoma.

Most published reports on subependymomas represent smaller and retrospective cohorts [2, 57-65]. The largest report of Elisabeth Rushing et al. comprised 83 cases, but focused on histopathological findings and does not consider surgical aspects [2].

We report on 21 patients, representing the second largest "surgical" series published to date (Table 5) [2, 5765]. As radiation or systemic treatment do not apply for subependymomas, surgery remains the only viable option in this entity. The surgical strategy focusses on maximal but safe resection, resulting in permanent absence of the tumor. In the majority of reports, gross total resection could be achieved in $>70 \%$ of patients, with low rates of mortality and morbidity [2, 57-65]. In our cohort, we were able to achieve gross total resection in

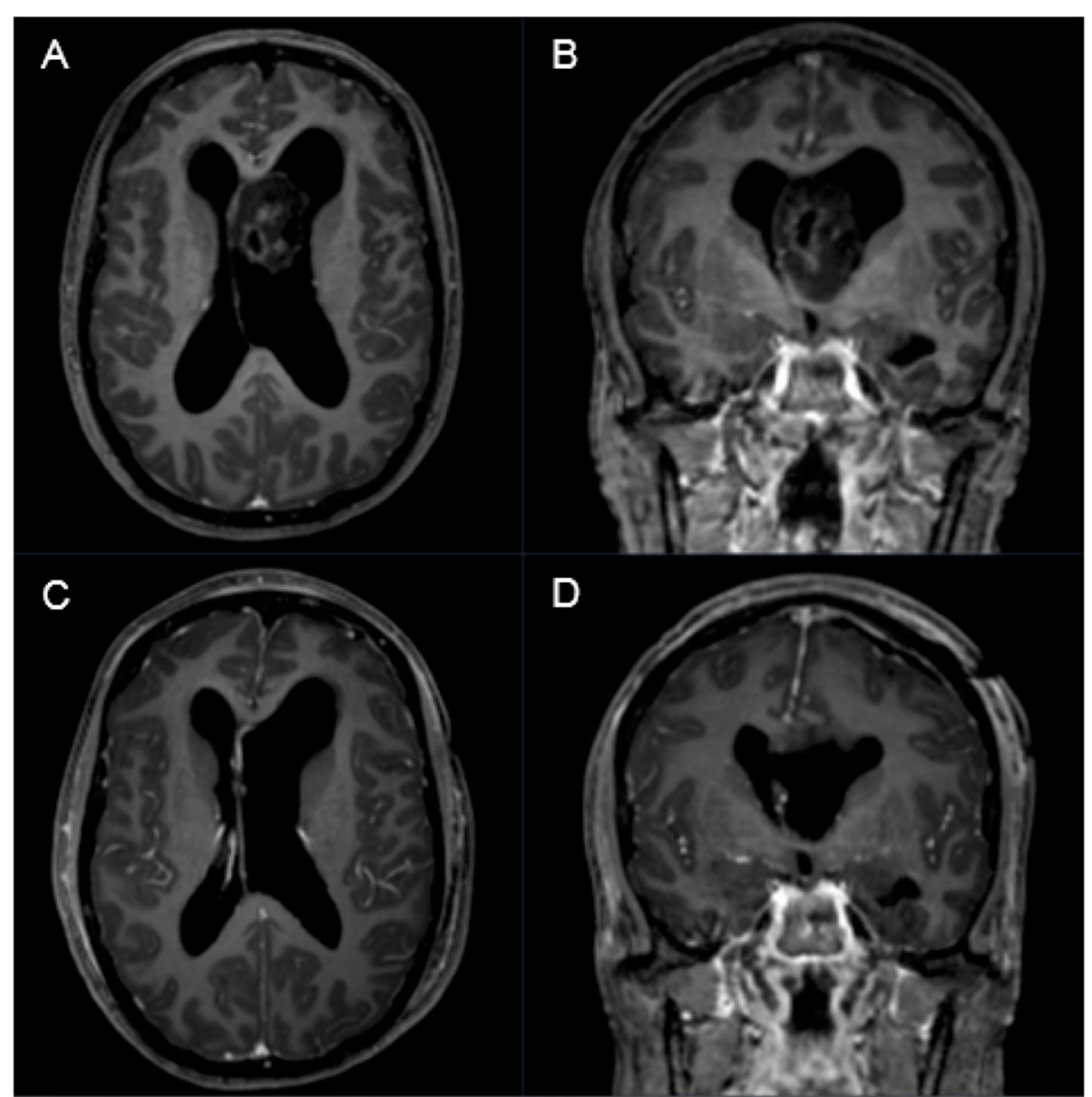

Fig. 3 A 44-year-old female patient presented with aggravating headache, vertigo, gait disturbance and concentration disorder in sense of hydrocephalic symptoms for 3-4 months. a, b Preoperative T1-weighted gadolinium enhanced MRI showing a low to intermediate heterogeneously enhancing intraventricular mass in the third ventricle with consecutive secondary hydrocephalus. c, d Postoperative T1weighted gadolinium enhanced MRI showing complete removal of the tumor through a left frontal precoronary transventricular keyhole approach. Pathological findings confirmed WHO grade I subependymoma 
Table 5 Case series since 2000 of resected subependymomas

\begin{tabular}{|c|c|c|c|c|c|}
\hline Study & Patients & Location & Complete removal & Recurrence & Mortality \\
\hline Nishio et al. [59] & 4 & Lateral ventricle. & $75.0 \%$ & 0 & 0 \\
\hline Im et al. [60] & 7 & $\begin{array}{l}\text { Lateral ventricle (6) } \\
\text { 3rd ventricle (1) }\end{array}$ & $71.0 \%$ & $29.0 \%$ & 0 \\
\hline Mallik et al. [61] & 5 & 3rd ventricle (1) 4th ventricle (4) & n.m. & $50.0 \%$ & $20.0 \%$ \\
\hline Ragel et al. [58] & 8 & $\begin{array}{l}\text { Lateral ventricle (2) } \\
4 \text { th ventricle (3) } \\
\text { Supratentorial lobar (2) } \\
\text { Spinal cord (1) }\end{array}$ & $100 \%$ & 0 & 0 \\
\hline Rushing et al. [2] & $34 \%$ & $\begin{array}{l}\text { Lateral ventricle (17) } \\
\text { 4th ventricle (15) } \\
\text { Others n.m. }\end{array}$ & $53.0 \%$ & n.m. & $18 \%$ \\
\hline Limaiem et al. [62] & 6 & $\begin{array}{l}\text { Lateral ventricle (5) } \\
\text { 4th ventricle (1) }\end{array}$ & $83.3 \%$ & 0 & 0 \\
\hline Fujisawa et al. [63] & 5 & Lateral ventricle (5) & $100 \%$ & 0 & 0 \\
\hline Kandenwein et al. [57] & 11 & $\begin{array}{l}\text { Lateral ventricle (4) } \\
\text { 4th ventricle (7) }\end{array}$ & $73.0 \%$ & $9.0 \%$ & 0 \\
\hline Varma et al. [64] & 13 & $\begin{array}{l}\text { Lateral ventricle (5) } \\
\text { 3rd ventricle (1) } \\
\text { 4th ventricle (8) }\end{array}$ & $92.3 \%$ & 0 & 0 \\
\hline Hou Z et al. [65] & 26 & Lateral ventricle (26) & $85.0 \%$ & 0 & $3.8 \%$ \\
\hline Aftahy et al. (present series) & 21 & $\begin{array}{l}\text { Lateral ventricle (11) } \\
\text { 4th ventricle (10) }\end{array}$ & $100 \%$ & 0 & $4.8 \%$ \\
\hline
\end{tabular}

all cases $(21 / 21)$ with a surgery-related mortality rate of $4,8 \%$.

\section{Central Neurocytoma}

The central neurocytoma is a rare brain tumor with a frequency of $0.1-0.5 \%$ of all intracranial central nervous tumors. It is a benign WHO grade II tumor with a 5year survival of $89 \%[1,66,67]$. The origin of these tumors remains unclear, but cell-culture investigations proclaim origin from bipotential progenitor cells that are capable of both neuronal and glial differentiation $[4,68]$.

They are typically located in lateral ventricles and/or the third ventricle (Fig. 4). The anterior portion of one lateral ventricle is the most frequent site (50\%), followed by combined involvement of the lateral and third ventricles $(15 \%)$ and the involvement of both lateral ventricles (13\%). Surgical resection is primary treatment for central neurocytomas but may also include radiation or systemic therapy. Extend of resection correlates with the rate of recurrence. Patients undergoing subtotal resection are commonly treated with adjuvant stereotactic radiation therapy, resulting in improved outcome compared to surgery alone [69].

Extraventricular neurocytomas are also described and occur in the brain parenchyma, cerebellum or spinal cord [70]. The term "central neurocytoma" is related to the ventricular system.

The tumor's rarity makes it challenging to define treatment standards. Most institutions, including our center, regrade surgical gross total resection as gold standard for treatment of central neurocytomas with complete removal rates of $30-50 \%$ [70-73]. In this cohort, we achieved gross total resection in $90.0 \%(9 / 10)$ [72, 7476] (Table 6).

After total resection, a five-year survival rate of $99 \%$ is reported [70, 77-80], compared to $86 \%$ in cases of subtotal resection [79]. Nevertheless, they do not emphasize on adjuvant therapy strategies. This is backed by a pooled analysis by Rades with over 400 cases, which demonstrates superiority of gross total resection regarding overall survival [71]. However, this is in contrast to a series of 45 central neurocytomas showing no significant difference in local tumor control or survival comparing complete and incomplete resection including adjuvant therapy [75]. A systematic review by Garcia et al. displayed that extent of resection was not predictive regarding improved local control [81], while a prospective multi-center study reported that in 71 patients, those with subtotal resection had a 3,8 times higher risk of recurrence [82]. The role of gross total resection remains ambiguous, with several treatment pathways including external beam radiation therapy, stereotactic radiosurgery, re-operation and/or chemotherapy [72]. Whether pathological subtypes or molecular patterns of central neurocytomas play a role in the course of disease and should guide therapy strategies remains .Table 6 highlights the multimodal treatment options of different institutions and their different outcomes [72, 74-76]. 


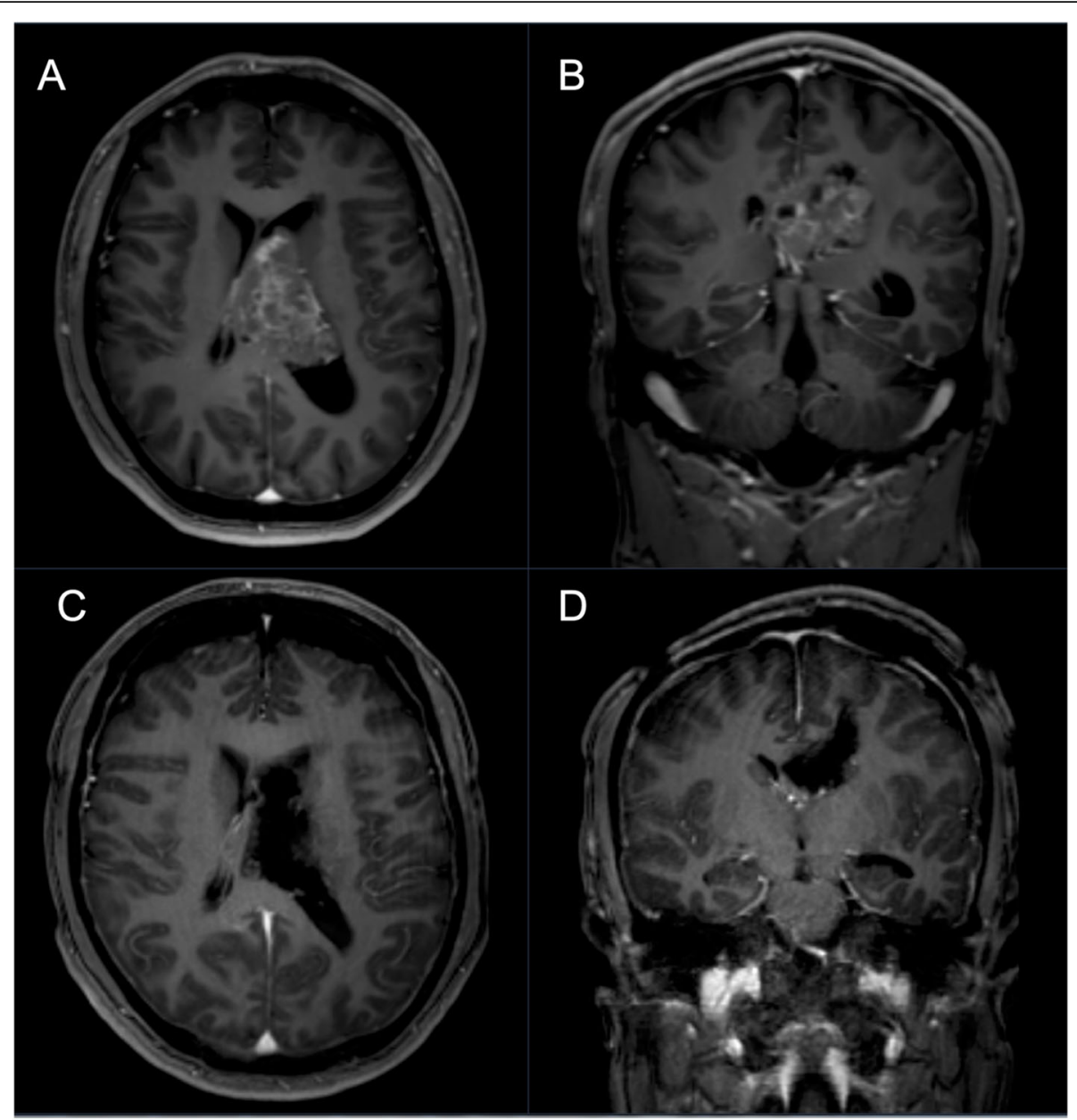

Fig. 4 A 32-year-old male patient presented with severe headache, diplopia, vertigo, nausea and a right sided hemiparesis for 2 weeks. a, b Central neurocytomas appear slightly hypo-intense to iso-intense on T1-weighted and iso-intense to hyper-intense on T2-weighted MRI (hypointensity can indicate the presence of a hemorrhage, cyst, or calcification). Typically, moderate gadolinium enhancement is seen. c, $\mathbf{d}$ Postoperative T1-weighted gadolinium enhanced MRI showing complete removal of the tumor via a left frontal precoronary transcortical keyhole approach. Pathologicalfindings confirmed WHO grade II central neurocytoma

Hallock et al. confirmed that gross total resection can be associated with durable long-term outcome and should be first line therapy, but also reported that subtotal resection with no further adjuvant treatment can be seen as salvage treatment with surgery or radiation at the time of clinical and radiographic progression. Nevertheless, he also reported a recurrence rate of about $33 \%$ with majority of recurrences within 2.5 years of surgery [76].

Other studies advocated postoperative adjuvant radiotherapy for improved local control of central neurocytomas, but radiation related adverse events of $>60 \%$ should be taken into careful consideration [83, 84]. Nevertheless, stereotactic radiosurgery shows promising results in a report of recurrent or residual neurocytomas [85].

Based on our findings we recommend safe, gross total resection to be the first line therapy. In case of recurrence, individual decisions according to overall patient's condition, tumor location, age and patient's preference should guide the mode of therapy.

\section{Glioependymal cyst (GEC)}

The etiology of GECs remains controversial as actual theories on its natural history fail to demonstrate why those cysts occur in different anatomical locations and also do not explain the histological variability in the cyst wall [86]. They are counted to congenital benign lesions with a neuroectodermal origin that share many radiological characteristics with other neuroepithelial lesions. Diagnosis of GECs is confirmed by histological examination [87]. Yasaragil et al. proclaimed that GECs could originate from the tela choroidea migrated somehow during embryogenesis towards brain parenchyma or subarachnoid place [88], resulting in various tumor locations. A systemic review highlighted the difficulties of grouping GECs as few case reports and series are 
Table 6 Major case series since 2000 of multimodal treated central neurocytomas $(N<10)$. Note the different treatment options and outcome findings

\begin{tabular}{|c|c|c|c|c|c|}
\hline Study & Patients & Treatments & Complete removal & Outcome & Mortality \\
\hline Sharma et al. [74] & 20 & $\begin{array}{l}\text { GTR } 70.0 \%(14)+\text { RT } \\
\text { STR 30.0\% (6) + RT }\end{array}$ & $70.0 \%(14)$ & 15/20 OS: $66.7 \%$ & $25 \%$ \\
\hline Leenstra et al. [75] & 45 & $\begin{array}{l}\text { GTR (15) } \\
\text { STR (14) } \\
\text { GTR/RT (4) } \\
\text { STR/RT (7) } \\
\text { GTR/RT/CH (2) } \\
\text { STR/RT/CH (1) } \\
\text { Bx/RT (2) }\end{array}$ & $46.6 \%(21)$ & $\begin{array}{l}\text { 10y OS: } 83.0 \% \\
\text { 10y LC: } 60.0 \%\end{array}$ & n.m. \\
\hline Hallock et al. [76] & 20 & $\begin{array}{l}\text { GTR (10) } \\
\text { STR (8) } \\
\text { STR/RT (1) } \\
\text { No treatment (1) }\end{array}$ & $50.0 \%(10)$ & $\begin{array}{l}\text { 10y OS: } 82.0 \% \\
\text { 10y LC: } 61.0 \%\end{array}$ & n.m. \\
\hline Imber et al. [72] & 28 & $\begin{array}{l}\text { GTR (8) } \\
\text { STR (16) } \\
\text { GTR/EBRT (1) } \\
\text { STR/RT (3) }\end{array}$ & $32.1 \%(9)$ & $\begin{array}{l}\text { 5y PFS: } 40.0 \% \\
\text { 5y PFS: } 53.0 \% \\
\text { n.m. } \\
\text { 5y PFS: } 67.0 \%\end{array}$ & 5y OS: $96.0 \%, 10 y$ OS: $82.0 \%$ \\
\hline Aftahy et al. (present series) & 10 & $\begin{array}{l}\text { GTR (9) } \\
\text { STR (1) }\end{array}$ & $90.0 \%(9 / 10)$ & 2y OS: $100 \%$ & $0 \%$ \\
\hline
\end{tabular}

GTR: gross total resection; STR: subtotal resection; RT: radiotherapy; $\mathrm{CH}$ : chemotherapy; EBRT: external beam radiotherapy; Bx: biopsy; OS: overall survival; PFS: progression free survival; LC: local control; SD: standard deviation

published. Treatment of GECs is indicated if they become symptomatic, whereas surgical approach and goal should be tailored on the individual's condition [87]. Our case was confirmed by histopathological examination. Surgical decision for complete resection of the cystic tumorous intraventricular lesion was based on the fact that the young, 18 years old patient was admitted due to an acute loss of consciousness and MRI revealed a symptomatic hydrocephalus caused by the lesion. Intraoperatively, the cyst was fenestrated but also tumorous suspicious tissue was detected sticked to the caudate head together with the cyst membrane. As the intraoperative findings were not clear, decision was made to completely resect the cystic lesion. This individual surgical decision was tailored on the current condition and situation (young patient, acute symptoms, suspicious intraoperative findings, possible and feasible complete resection).

\section{Study limitations}

Our study harbors several flaws and limitations. As it is a retrospective case series, causalities are not possible to draw with respect to clinical outcome. Nevertheless, detailed clinical examination including scores on functional performance as well as a standardized follow up protocol based on a certified neurooncological board are implemented in our clinical workflow. Given the rarity of these lesions prospective inclusion and follow up is hard to achieve within a reasonable time period. Having this in mind, even though we report a relatively large single center series, the absolute amount of cases does not allow for proper statistical analysis. We recommend that, multi-center studies should be conducted to address this problem. In our study we do not focus on long term outcome of different tumor entities, but more on the surgical approach and perioperative outcome. If one wants to address therapy strategies in a whole of these rare lesions, further histopathological, molecular and gene markers have to be taken into account to guide individual therapy strategies. Another problem in rare surgical entities is reflected by the changing therapy modalities, that may bias the therapy outcome, reflected by a learning curve of treating surgeons, various surgeons involved in the treatment or changes in surgical technique. Therefore, in our cohort we limit the report on classic microsurgical approaches. The role of intraventricular endoscopy is not reflected in our series. Even more, local tumor treating strategies like local drug perfusion catheters or laser interstitial thermal therapy might become more important in the future treatment of deep located lesions. Besides its retrospective nature, the analysed patient collective suffers from certain heterogeneities. The different types of IVTs may create inhomogeneity. The number of patients with central neurocytomas and GEC was limited to 10 and 1, respectively, out of 45 total patients, which could lead to variability in the results. We included them in the analysis because all aspects of IVTs should be reflected and because basic surgical techniques are similar for IVTs.

\section{Conclusion}

Our surgical findings emphasize safe complete resection throughout all above analyzed neuroepithelial lesions. Surgical treatment can remain both safe and feasible, if 
institutional experience is given. Satisfying long-term survival and also cure is possible by complete removal. Regarding complete resected subependymomas shorter follow-up can be discussed, too. It should be noted, that gross total resection should always be performed under functional improving aspects due to mostly benign nature of IVTs. Further data is needed to evaluate standard of care and alternative therapy options in rare cases of tumor recurrence or in case of patient collective not suitable for operative resection.

\section{Abbreviations}

CDG: Clavien Dindo Scale; CSF: Cerebrospinal Fluid; FSRT: Fractionated Stereotactic Radiotherapy; GEC: Glioependymal cyst; IEAE: Extra-axial ependymomas exist; IVT: Intraventricular neuroepithelial tumors; KPSS: Karnofsky Performance Status Scale; MRI: Magnet Resonance Imaging; WHO: World Health Organization

\section{Acknowledgments}

Not applicable.

\section{Authors' contributions}

Conceptualization: KA; Methodology: KA, MB; Formal analysis and investigation: KA, MB; Writing - original draft preparation: KA; Writing - review and editing: PK, FL, BW, SEC, CS, BM, JG; Supervision: BM, JG. All authors have read and approved the manuscript.

\section{Funding}

Not applicable. Open Access funding enabled and organized by Projekt DEAL.

\section{Availability of data and materials}

The datasets used and/or analysed during the current study are available from the corresponding author on reasonable request.

\section{Ethics approval and consent to participate}

The local ethics committee of the Technical University Munich, School of Medicine, approved our study (231/20 S-EB). We conducted it in accordance with the ethical standards of the 1964 Declaration of Helsinki and its later amendments [22]. The requirement for written informed consent was waived by the ethics committee.

\section{Consent for publication}

Not applicable.

\section{Competing interests}

JG and Bernhard Meyer BM work as consultants for Brainlab (Brainlab AG, Feldkirchen). In addition, BM works as a consultant for Medtronic, Spineart, Icotec, Relievant and Depuy/Synthes. In these firms, BM acts as a member of the advisory board. Furthermore, BM reports a financial relationship with Medtronic, Ulrich Medical, Brainlab, Spineart, Icotec, Relievant and Depuy/ Synthes. He received personal fees and research grants for clinical studies from Medtronic, Ulrich Medical, Brainlab, Icotec and Relievant. All this happened independently of the submitted work. BM holds the royalties/ patent for Spineart. All named potential conflicts of interest are unrelated to this study. There are no further conflicts of interest regarding the other authors.

\section{Author details}

${ }^{1}$ Department of Neurosurgery, Technical University Munich, Medical Faculty, School of Medicine, Klinikum rechts der Isar, Ismaninger Str. 22, 81675 Munich, Germany. ${ }^{2}$ Department of Neuropathology, Technical University Munich, School of Medicine, Klinikum rechts der Isar, Institute of Pathology, Munich, Germany. ${ }^{3}$ Department of Neuroradiology, Technical University Munich, School of Medicine, Klinikum rechts der Isar, Munich, Germany. ${ }^{4}$ Department of Radiation Oncology, Technical University Munich, School of Medicine, Klinikum rechts der Isar, Munich, Germany. ${ }^{5}$ Department of Radiation Sciences (DRS) Helmholtz Zentrum Munich, Institute of Innovative
Radiotherapy (iRT), Munich, Germany. ${ }^{6}$ German Cancer Consortium (DKTK), Partner Site Munich, Munich, Germany.

Received: 7 August 2020 Accepted: 26 October 2020

Published online: 03 November 2020

\section{References}

1. Louis DN, Perry A, Reifenberger G, von Deimling A, Figarella-Branger D, Cavenee WK, et al. The 2016 World Health Organization classification of tumors of the central nervous system: a summary. Acta Neuropathol. 2016; 131(6):803-20.

2. Rushing EJ, Cooper PB, Quezado M, Begnami M, Crespo A, Smirniotopoulos JG, et al. Subependymoma revisited: clinicopathological evaluation of 83 cases. J Neuro-Oncol. 2007;85(3):297-305.

3. Kleihues P, Louis DN, Scheithauer BW, Rorke LB, Reifenberger G, Burger PC, et al. The WHO classification of tumors of the nervous system. J Neuropathol Exp Neurol. 2002;61(3):215-25 discussion 26-9.

4. Louis DN, Swearingen B, Linggood RM, Dickersin GR, Kretschmar C, Bhan AK, et al. Central nervous system neurocytoma and neuroblastoma in adults--report of eight cases. J Neuro-Oncol. 1990;9(3):231-8.

5. Oppenheim H. Operative Erfolgebei Geschwulsten der Sehhugel-and Vierhugel-gegend. Berl Klin Wchschr. 1913;50:2316-22.

6. Jamieson KG. Excision of pineal tumors. J Neurosurg. 1971;35(5):550-3.

7. Poppen $J \mathrm{~L}$, Marino R Jr. Pinealomas and tumors of the posterior portion of the third ventricle. J Neurosurg. 1968;28(4):357-64.

8. Dandy W. An operation for the removal of pineal tumors. Surg Gynecol Obstet. 1921;33:113-9.

9. Ebrahim KS, Toubar AF. Telovelar approach versus transvermian approach in management of fourth ventricular tumors. Egypt J Neurosurg. 2019;34(1):10.

10. Ziyal IM, Sekhar LN, Salas E. Subtonsillar-transcerebellomedullary approach to lesions involving the fourth ventricle, the cerebellomedullary fissure and the lateral brainstem. Br J Neurosurg. 1999;13(3):276-84.

11. Ezer $H$, Banerjee $A D$, Bollam P, Guthikonda B, Nanda A. The superior transvelar approach to the fourth ventricle and brainstem. J Neurol Surg B Skull Base. 2012;73(3):175-82.

12. Zymberg ST, Paiva Neto MA, Gorgulho AAP, Cavalheiro S. Endoscopic approach to fourth ventricle cysticercosis. Arq Neuropsiquiatr. 2003;61:204-7.

13. Yano S, Hide T, Shinojima N, Ueda Y, Kuratsu J. A flexible endoscopeassisted interhemispheric transcallosal approach through the contralateral ventricle for the removal of a third ventricle craniopharyngioma: a technical report. Surg Neurol Int. 2015:6(Suppl 2):S113-6.

14. Winkler EA, Birk H, Safaee M, Yue JK, Burke JF, Viner JA, et al. Surgical resection of fourth ventricular ependymomas: case series and technical nuances. J Neuro-Oncol. 2016;130(2):341-9.

15. Rekate HL, Grubb RL, Aram DM, Hahn JF, Ratcheson RA. Muteness of cerebellar origin. JAMA Neurol. 1985;42(7):697-8.

16. Cikla U, Swanson Kl, Tumturk A, Keser N, Uluc K, Cohen-Gadol A, et al. Microsurgical resection of tumors of the lateral and third ventricles: operative corridors for difficult-to-reach lesions. J Neuro-Oncol. 2016;130(2): 331-40.

17. Yasargil MG, Abdulrauf SI. Surgery of intraventricular tumors. Neurosurgery. 2008;62(6 Suppl 3):1029-40 discussion 40-1.

18. Ellenbogen RG. Transcortical surgery for lateral ventricular tumors Neurosurg Focus. 2001;10(6):1.

19. Rhoton AL Jr. The lateral and third ventricles. Neurosurgery. 2002;51(4 Suppl):S207-71.

20. Piepmeier J, Spencer D, Sass K, George T. Brain surgery: complication avoidance and management; 1993.

21. Asgari S, Engelhorn T, Brondics A, Sandalcioglu IE, Stolke D. Transcortical or transcallosal approach to ventricle-associated lesions: a clinical study on the prognostic role of surgical approach. Neurosurg Rev. 2003;26(3):192-7.

22. World Medical Association. World Medical Association Declaration of Helsinki: ethical principles for medical research involving human subjects. JAMA. 2013;310(20):2191-4. https://doi.org/10.1001/jama.2013.281053. PMID: 24141714

23. Yaşargil MG. Microneurosurgery: microsurgery of CNS tumors: instrumentation and equipment, Laboratory, Training, Surgical Approaches, Strategies, Tactics and Techniques, Surgery and Results of Extrinsic and Intrinsic Tumors, Interventional Neuroradiology, Neuroanesthesia, Complications: Thieme; 1996 
24. Transcortical approach exposing the lateral and third ventricles. Keyhole Approaches in Neurosurgery: Volume I Concept and surgical technique. Vienna: Springer Vienna; 2008. p. 267-82.

25. Mussi ACM, Rhoton AL. Telovelar approach to the fourth ventricle: microsurgical anatomy. 2000;92(5):812.

26. Deshmukh VR, Figueiredo EG, Deshmukh P, Crawford NR, Preul MC, Spetzler RF. Quantification And Comparison Of Telovelar And Transvermian Approaches To The Fourth Ventricle. Operative Neurosurg. 2006;58(suppl_4): ONS-202-ONS-7.

27. El-Bahy K. Telovelar approach to the fourth ventricle: operative findings and results in 16 cases. Acta Neurochir. 2005;147(2):137-42 discussion 42.

28. Zaheer SN, Wood M. Experiences with the Telovelar approach to fourth ventricular tumors in children. Pediatr Neurosurg. 2010;46(5):340-3.

29. Sarnthein J, Bozinov O, Melone AG, Bertalanffy H. Motor-evoked potentials (MEP) during brainstem surgery to preserve corticospinal function. Acta Neurochir. 2011;153(9):1753-9.

30. Smith AB, Smirniotopoulos JG, Horkanyne-Szakaly I. From the radiologic pathology archives: intraventricular neoplasms: radiologic-pathologic correlation. Radiographics. 2013;33(1):21-43.

31. Koeller KK, Sandberg GD. Armed forces Institute of P. from the archives of the AFIP. Cerebral intraventricular neoplasms: radiologic-pathologic correlation. Radiographics. 2002;22(6):1473-505.

32. Asaid M, Preece PD, Rosenthal MA, Drummond KJ. Ependymoma in adults: local experience with an uncommon tumour. J Clin Neurosci. 2015;22(9): 1392-6.

33. Wu J, Armstrong TS, Gilbert MR. Biology and management of ependymomas. Neuro-Oncology. 2016;18(7):902-13.

34. Ma L, Xiao SY, Liu XS, You C, Zhang YK. Intracranial extraaxial ependymoma in children: a rare case report and review of the literature. Neurol Sci. 2012; 33(1):151-4.

35. Berhili S, Aissa A, Kadiri S, Cherradi N, El Majjaoui S, El Kacemi H, et al. Extraaxial ependymoma of the cerebral convexity: a very rare intracranial adult tumor. Neuroradiol J. 2017;30(3):281-5.

36. Yang Y, Tian K-B, Hao S-Y, Wu Z, Li D, Zhang J-T. Primary Intracranial ExtraAxial Anaplastic Ependymomas. World Neurosurg. 2016;90(704):e1-9.

37. Healey EA, Barnes PD, Kupsky WJ, Scott RM, Sallan SE, Black PM, et al. The prognostic significance of postoperative residual tumor in ependymoma. Neurosurgery. 1991;28(5):666-71 discussion 71-2

38. Pejavar S, Polley MY, Rosenberg-Wohl S, Chennupati S, Prados MD, Berger MS, et al. Pediatric intracranial ependymoma: the roles of surgery, radiation and chemotherapy. J Neuro-Oncol. 2012;106(2):367-75.

39. Rhoton AL Jr. The Cerebellopontine Angle and Posterior Fossa Cranial Nerves by the Retrosigmoid Approach. Neurosurgery. 2000;47(suppl_3):S93-S129.

40. Chai YH, Jung S, Lee JK, Kim IY, Jang WY, Moon KS, et al. Ependymomas: prognostic factors and outcome analysis in a retrospective series of 33 patients. Brain Tumor Res Treat. 2017:5(2):70-6.

41. Rajesh BJ, Rao BR, Menon G, Abraham M, Easwer HV, Nair S. Telovelar approach: technical issues for large fourth ventricle tumors. Childs Nerv Syst. 2007;23(5):555-8.

42. Tomasello F, Conti A, Cardali S, La Torre D, Angileri FF. Telovelar approach to fourth ventricle tumors: highlights and limitations. World Neurosurg. 2015;83(6):1141-7.

43. Gok A, Alptekin M, Erkutlu I. Surgical approach to the fourth ventricle cavity through the cerebellomedullary fissure. Neurosurg Rev. 2004;27(1):50-4.

44. Spagnoli D, Tomei G, Ceccarelli G, Grimoldi N, Lanterna A, Bello L, et al. Combined treatment of fourth ventricle ependymomas: report of 26 cases. Surg Neurol. 2000;54(1):19-26 discussion.

45. Rudà R, Reifenberger G, Frappaz D, Pfister SM, Laprie A, Santarius T, et al. EANO guidelines for the diagnosis and treatment of ependymal tumors. Neuro-oncology. 2018;20(4):445-56.

46. Mahajan A, Ahmed S, McAleer MF, Weinberg JS, Li J, Brown P, et al. Postoperative stereotactic radiosurgery versus observation for completely resected brain metastases: a single-Centre, randomised, controlled, phase 3 trial. Lancet Oncol. 2017;18(8):1040-8.

47. Ghia AJ, Mahajan A, Allen PK, Armstrong TS, Lang FF, Gilbert MR, et al. Supratentorial gross-totally resected non-anaplastic ependymoma: population based patterns of care and outcomes analysis. J Neuro-Oncol. 2013;115(3):513-20.

48. Metellus P, Guyotat J, Chinot O, Durand A, Barrie M, Giorgi R, et al. Adult intracranial WHO grade II ependymomas: long-term outcome and prognostic factor analysis in a series of 114 patients. Neuro-oncology. 2010;12(9):976-84.
49. Nuno M, Yu JJ, Varshneya K, Alexander J, Mukherjee D, Black KL, et al. Treatment and survival of supratentorial and posterior fossa ependymomas in adults. J Clin Neurosci. 2016;28:24-30.

50. Mansur DB, Perry A, Rajaram V, Michalski JM, Park TS, Leonard JR, et al. Postoperative radiation therapy for grade II and III intracranial ependymoma. Int J Radiat Oncol Biol Phys. 2005;61(2):387-91.

51. Combs SE, Thilmann C, Debus J, Schulz-Ertner D. Local radiotherapeutic management of ependymomas with fractionated stereotactic radiotherapy (FSRT). BMC Cancer. 2006;6(1):222.

52. Bloom HJ, Glees J, Bell J, Ashley SE, Gorman C. The treatment and longterm prognosis of children with intracranial tumors: a study of 610 cases, 1950-1981. Int J Radiat Oncol Biol Phys. 1990;18(4):723-45.

53. Lombardi D, Scheithauer BW, Meyer FB, Forbes GS, Shaw EG, Gibney DJ, et al. Symptomatic subependymoma: a clinicopathological and flow cytometric study. J Neurosurg. 1991;75(4):583-8.

54. Scheithauer BW. Symptomatic subependymoma. Report of 21 cases with review of the literature. J Neurosurg. 1978;49(5):689-96.

55. Wiestler O, Schiffer D, Coons S, Prayson R, Rosenblum M. Pathology and genetics of tumors of the nervous system. Lyon, France: IARC; 2000. p. 227-30.

56. Pagni CA, Canavero S, Giordana MT, Mascalchi M, Arnetoli G. Spinal intramedullary subependymomas: case report and review of the literature. Neurosurgery. 1992;30(1):115-7.

57. Kandenwein JA, Bostroem A, Feuss M, Pietsch T, Simon M. Surgical management of intracranial subependymomas. Acta Neurochir. 2011;153(7):1469-75.

58. Ragel BT, Osborn AG, Whang K, Townsend JJ, Jensen RL, Couldwell WT. Subependymomas: an analysis of clinical and imaging features. Neurosurgery. 2006;58(5):881-90 discussion -90 .

59. Nishio S, Morioka T, Mihara F, Fukui M. Subependymoma of the lateral ventricles. Neurosurg Rev. 2000;23(2):98-103.

60. Im SH, Paek SH, Choi YL, Chi JG, Kim DG, Jung HW, et al. Clinicopathological study of seven cases of symptomatic supratentorial subependymoma. J Neuro-Oncol. 2003;61(1):57-67.

61. Mallik MK, Babu N, Kakkar N, Khosla VK, Banerjee AK, Vasishta RK. Subependymomas in children: a report of five cases including two with osseous metaplasia. Neurol India. 2003;51(1):98-9.

62. Limaiem F, Bellil SB, Bellil K, Chelly I, Jemel H, Haouet $\mathrm{S}$, et al. Subependymomas: a clinicopathological study of 6 symptomatic cases. Pathologica. 2008;100(5):401-4.

63. Fujisawa $\mathrm{H}$, Hasegawa M, Ueno M. Clinical features and management of five patients with supratentorial subependymoma. J Clin Neurosci. 2010;17(2): 201-4.

64. Varma A, Giraldi D, Mills S, Brodbelt AR, Jenkinson MD. Surgical management and long-term outcome of intracranial subependymoma. Acta Neurochir. 2018;160(9):1793-9.

65. Hou Z, Wu Z, Zhang J, Zhang L, Tian R, Liu B, et al. Lateral ventricular subependymomas: an analysis of the clinical features of 27 adult cases at a single institute. Neurol India. 2012;60(4):379-84.

66. Dutta SW, Kaleem TA, Muller DA, Peterson J, Harrell AC, Quinones-Hinojosa A, et al. Central neurocytoma: clinical characteristics, patterns of care, and survival. J Clin Neurosci. 2018;53:106-11.

67. Sander C, Wallenborn M, Brandt VP, Ahnert P, Reuschel V, Eisenlöffel $C$, et al. Central neurocytoma: SNP array analyses, subtel FISH, and review of the literature. Pathol Res Pract. 2019;215(7):152397.

68. Figarella-Branger D. Central neurocytoma. Pathology and genetics of tumours of the nervous system; 2000. p. 107-11.

69. Richardson AM, Armstrong VL, Gernsback JE, Gultekin SH, Komotar RJ. Central Neurocytoma: rare presentation in fourth ventricle and review of literature. World Neurosurgery. 2019;123:357-61.

70. Lee SJ, Bui TT, Chen CH, Lagman C, Chung LK, Sidhu S, et al. Central Neurocytoma: a review of clinical management and Histopathologic features. Brain Tumor Res Treat. 2016;4(2):49-57.

71. Rades D, Schild SE. Treatment recommendations for the various subgroups of neurocytomas. J Neuro-Oncol. 2006;77(3):305-9.

72. Imber BS, Braunstein SE, Wu FY, Nabavizadeh N, Boehling N, Weinberg VK, et al. Clinical outcome and prognostic factors for central neurocytoma: twenty year institutional experience. J Neuro-Oncol. 2016;126(1):193-200.

73. Byun J, Hong SH, Yoon MJ, Kwon SM, Cho YH, Kim JH, et al. Prognosis and treatment outcomes of central neurocytomas: clinical interrogation based on a single center experience. J Neuro-Oncol. 2018;140(3):669-77.

74. Sharma MC, Deb P, Sharma S, Sarkar C. Neurocytoma: a comprehensive review. Neurosurg Rev. 2006;29(4):270-85 discussion 85. 
75. Leenstra JL, Rodriguez FJ, Frechette CM, Giannini C, Stafford SL, Pollock BE, et al. Central neurocytoma: management recommendations based on a 35year experience. Int J Radiat Oncol Biol Phys. 2007;67(4):1145-54.

76. Hallock A, Hamilton B, Ang LC, Tay KY, Meygesi JF, Fisher BJ, et al. Neurocytomas: long-term experience of a single institution. Neurooncology. 2011;13(9):943-9.

77. Kim DG, Paek SH, Kim IH, Chi JG, Jung HW, Han DH, et al. Central neurocytoma: the role of radiation therapy and long term outcome. Cancer. 1997;79(10):1995-2002.

78. Schild SE, Scheithauer BW, Haddock MG, Schiff D, Burger PC, Wong WW et al. Central neurocytomas. Cancer. 1997;79(4):790-5.

79. Rades D, Fehlauer F. Treatment options for central neurocytoma. Neurology. 2002;59(8):1268-70.

80. Bertalanffy A, Roessler K, Koperek O, Gelpi E, Prayer D, Knosp E. Recurrent central neurocytomas. Cancer. 2005:104(1):135-42.

81. Garcia RM, Ivan ME, Oh T, Barani I, Parsa AT. Intraventricular neurocytomas: a systematic review of stereotactic radiosurgery and fractionated conventional radiotherapy for residual or recurrent tumors. Clin Neurol Neurosurg. 2014; 117:55-64.

82. Vasiljevic A, Francois $P$, Loundou A, Fevre-Montange M, Jouvet $A$, Roche $P H$, et al. Prognostic factors in central neurocytomas: a multicenter study of 71 cases. Am J Surg Pathol. 2012:36(2):220-7.

83. Paek SH, Han JH, Kim JW, Park CK, Jung HW, Park SH, et al. Long-term outcome of conventional radiation therapy for central neurocytoma. J Neuro-Oncol. 2008;90(1):25-30.

84. Chen YD, Li WB, Feng J, Qiu XG. Long-term outcomes of adjuvant radiotherapy after surgical resection of central neurocytoma. Radiat Oncol. 2014;9:242.

85. Genc A, Bozkurt SU, Karabagli P, Seker A, Bayri Y, Konya D, et al. Gamma knife radiosurgery for cranial neurocytomas. J Neuro-Oncol. 2011;105(3):647-57.

86. Gilles FH, Rockett FX. Infantile hydrocephalus: retrocerebellar "arachnoidal" cyst. J Pediatr. 1971;79(3):436-43.

87. Robles LA, Paez JM, Ayala D, Boleaga-Duran B. Intracranial glioependymal (neuroglial) cysts: a systematic review. Acta Neurochir. 2018;160(7):1439-49.

88. Friede RL, Yasargil MG. Supratentorial intracerebral epithelial (ependymal) cysts: review, case reports, and fine structure. J Neurol Neurosurg Psychiatry. 1977;40(2):127-37.

\section{Publisher's Note}

Springer Nature remains neutral with regard to jurisdictional claims in published maps and institutional affiliations.

Ready to submit your research? Choose BMC and benefit from:

- fast, convenient online submission

- thorough peer review by experienced researchers in your field

- rapid publication on acceptance

- support for research data, including large and complex data types

- gold Open Access which fosters wider collaboration and increased citations

- maximum visibility for your research: over $100 \mathrm{M}$ website views per year

At $\mathrm{BMC}$, research is always in progress.

Learn more biomedcentral.com/submissions 